\title{
MOLLUSCS AND OSTRACODS OF THE QARUN LAKE: PRELIMINARY REPORT FROM FA-1 CORE IN FAIYUM OASIS, NORTHERN EGYPT
}

\author{
Marcin Szymanek \\ University of Warsaw, Faculty of Geology, Warsaw, Poland, e-mail: m.szymanek@uw.edu.pl
}

\begin{abstract}
A research was conducted on the Holocene lake sediments from the full-cored FA-1 drilling at the southern shore of the Qarun Lake in the Faiyum Oasis in northern Egypt. Altogether 10 taxa of molluscs and 8 taxa of ostracods were identified in the examined deposits, with total amounts of 768 and 2872 individuals, respectively. The fauna was investigated with palaeoecological purpose and allowed for preliminary reconstruction of sedimentary environment in the lake. The occurrence of Valvata nilotica Jickeli, 1874 and Gomphocythere sp. in the lower part of the core and a low proportion of carapaces (2.4-28\%) indicated freshwater and higher-energy conditions, respectively. Rapid expansion of Cyprideis torosa (Jones, 1850) at a depth of $18 \mathrm{~m}$ could point to very short saline episode in the lake. The increase in salinity and drop of water level were evidenced in the uppermost part of the core (4-3.5 $\mathrm{m}$ ), when the lake was dominated by Hydrobia ventrosa (Montagu, 1803), Cerastoderma glaucum (Poiret, 1789) and C. torosa. The steady sedimentation in a shallow lake was also supported by considerable amount of complete ostracod carapaces (45\%). The faunal assemblage and smooth valves of $C$. torosa suggested salinity of $14-25 \%$.
\end{abstract}

Key words: Molluscs, ostracods, Holocene, Qarun Lake, Egypt

Manuscript received 8 January 2017, accepted 17 April 2017

\section{INTRODUCTION}

The Qarun Lake (292 $6^{\prime} 36^{\prime \prime}-29^{\circ} 31^{\prime} 15^{\prime \prime} \mathrm{N}$ and $30^{\circ} 23^{\prime} 52^{\prime \prime}$ $\left.-30^{\circ} 49^{\prime} 55^{\prime \prime} \mathrm{E}\right)$ is located in the deepest part (43-44 m b.s.1.) of the vast Faiyum Oasis in northern Egypt, approximately $100 \mathrm{~km}$ south-west of Cairo (Fig. 1). Today, this shallow (mean and maximum depths of 4.2 and $8.5 \mathrm{~m}$, respectively) and saline lake is approximately $40 \mathrm{~km}$ long and $5.7 \mathrm{~km}$ wide. It occupies an area of about $250 \mathrm{~km}^{2}$ (Hughes and Hughes, 1992; El-Sayed and Guindy, 1999), which constitutes about $15 \%$ of the former lake basin occurring here since the early Holocene (cf. Caton-Thompson and Gardner, 1934; Wendorf and Schild, 1976). The lake formation was possible due to seasonal connections and distinct support of the Nile flood water, that occurred in the Faiyum Oasis since the early Holocene (e.g. Revel et al., 2014; Marks et al., 2016; Welc, 2016). The Nile floods inwashed fluvial deposits to the Faiyum Oasis, which together with diatomites, lacustrine silt and clay, and aeolian sand belong to the Quaternary main facies in the study area. They are underlain by Pliocene and Late Miocene rock formations, as well as limestones, marls and sandstones of Eocene and Oligocene age (Marks et al., 2016; Welc, 2016).
The 26- $\mathrm{m}$ long full-cored FA-1 borehole $(10 \mathrm{~cm}$ in diameter) was drilled at the south-eastern shore of the Qarun Lake (Fig. 1). The lithological profile started with the early Holocene massive carbonate clay, covered by thin layer of sandy clayey silt and silty clay. Upwards, fine-laminated silt and clay occurred, with some mollusc remains noted at a depth of 18.9-18.7 $\mathrm{m}$. These deposits were covered by thickly-laminated silt and clay with distinct shell-bearing horizon in the depth interval of 4-3.5 m. The sedimentation ended with 2-m thick modern sediments (Fig. 2).

The FA-1 sequence is the longest, undisturbed and the most complete $\log$ in the region (e.g. Flower et al., 2012; Marks et al., 2016), providing valuable palaeoenvironmental and palaeoclimatic data indispensable for both the reconstruction of the Lake Qarun history and the Holocene climate change in northern Africa (Marks et al., 2016; Welc, 2016). This study briefly reports a composition of the molluscan and ostracod fauna of the FA-1 core. Its main goal was to recognise molluses and ostracods from the studied sequence and apply them as an indicator of palaeolake conditions in the Qarun Lake, with the emphasis laid on the lake depth and changes in the water salinity. Those interpretations were predicted to indicate some crucial points 


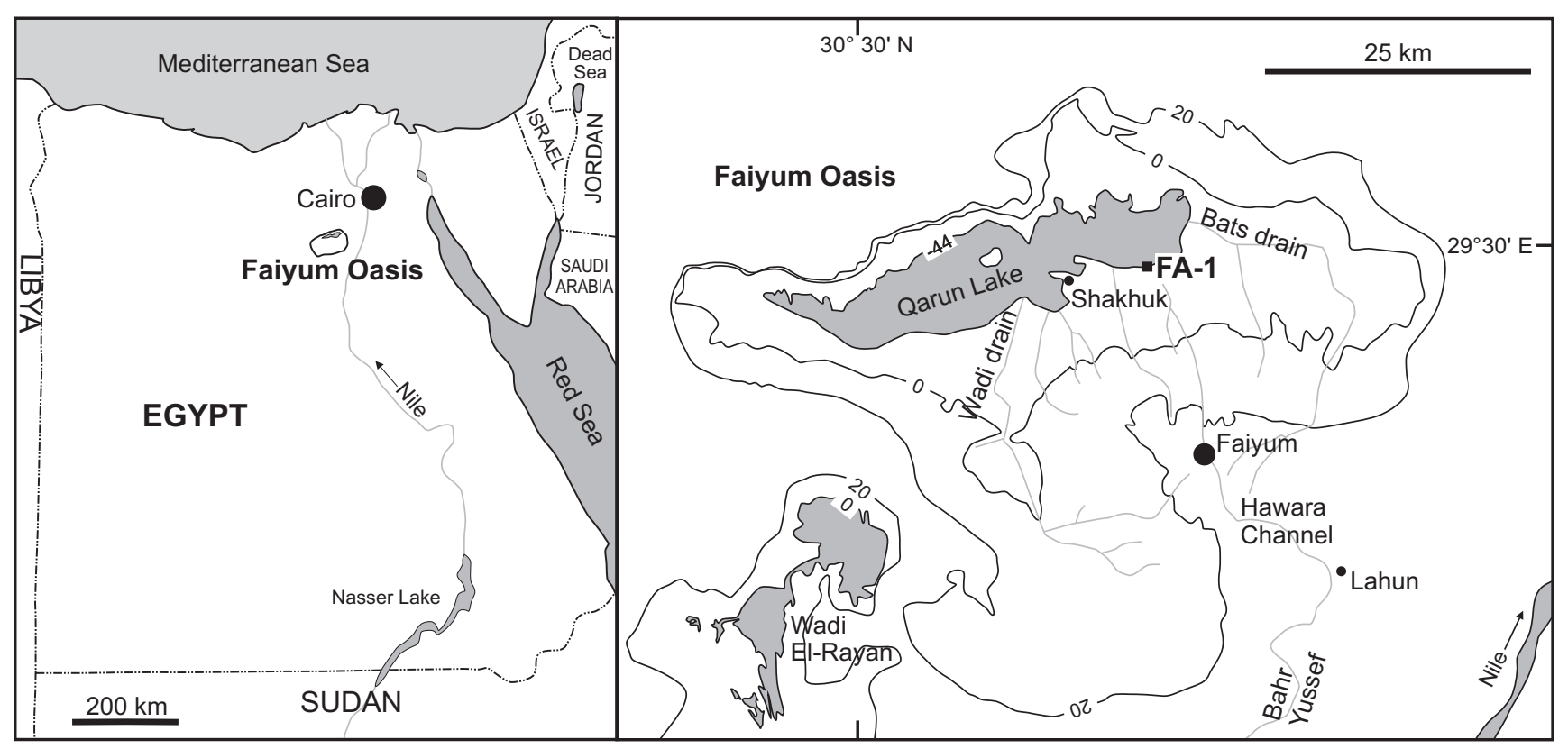

Fig. 1. Location sketch of the Lake Qarun and FA-1 core.

in the sequence and would be a base for further detailed reconstructions, supported by the high-resolution multidisciplinary studies comprising radiocarbon, geochemical and diatom analyses.

\section{MOLLUSC AND OSTRACOD INVESTIGATIONS IN THE FAIYUM OASIS}

The Holocene molluscs of the Faiyum Oasis were firstly described in the $19^{\text {th }}$ century (Martens, 1879), whereas the first studies on their systematics conducted by Gardner (1932) provided data on 25 taxa collected from the lake beaches and lake deposits; however, without detailed locations of the sampling sites (Hassan et al., 2012). In general, the mollusc assemblages of the early Holocene were dominated by freshwater bivalves of the genera Corbicula and Unio. In the middle Holocene abundant gastropods Melanoides sp. and Planorbis sp. occurred, but since $19^{\text {th }}$ century they have disappeared in the Lake Qarun, giving way to marine bivalve Cerastoderma glaucum (Hassan et al., 2012). Today, the latter constitutes even $70 \%$ of biomass of all molluscs in the lake, which are the main component of recent benthic fauna (Abdel Malek and Ishak, 1980; ElShabrawy and Dumont, 2009). According to Naguib (1961) C. glaucum is accompanied by abundant Pirenella and Mactra snails, while the comprehensive studies of plankton and benthic organisms are represented (apart from $C$. glaucum) by five gastropod species, namely Pirenella conica Blainville, 1829, Melanoides tuberculata (O.F. Müller, 1774), Hydrobia stagnalis (Baster, 1765) = Hydrobia ventrosa, Physa acuta Draparanaud, 1805 and Cleopatra bulimoides (Olivier, 1804) (Abdel Malek and Ishak, 1980). Sattman and Kinzelbach (1988) reported only on three mollusc species from the Qarun Lake assigned to two ecological groups. P. conica and Hinia costulata (Brocchi, 1814) represented snails of Mediterranean origin, whereas C. bulimoides was a snail of the Nile River Valley characteristic of the coarse-grained sediments (Sattman and Kinzelbach, 1988; Alexandrowicz, 2001). Its occurrence in the Faiyum Oasis was treated as a clear evidence of penetration of this region by the Nile during the middle Holocene (Alexandrowicz, 2001). This was also supported by similar compositions of subfossil mollusc assemblages from the Faiyum Oasis (radiocarbon dated at 7-6.5 ka BP) and the modern fauna of the Nile Valley containing, among others, C. bulimoides, Valvata nilotica, Theodoxus niloticus (Reeve, 1856), M. tuberculata, Gyraulus ehrenbergi (Beck, 1837) and Bulinus truncatus (Audouin, 1827) (Alexandrowicz, 1986, 2001).

Finally, mollusc shells have been also applied in geochemical studies of the Qarun Lake. Hassan et al. (2012) used stable oxygen and carbon isotopes of the shells collected at geoarchaeologically dated sequences to reconstruct both the palaeoenvironmental changes in the lake and palaeoclimatic variations in northern Africa throughout the Holocene, including dynamics of water level changes and the Nile floods discharge, as well as evaporation and precipitation rates. Seven mollusc taxa were used in these studies including Corbicula sp., Melanoides sp., Planorbis sp., Lymnaea sp., Cardium sp. and Coelatura sp. (Hassan et al., 2012). Based on high concentrations of trace metals in their bodies, the modern molluscs of the Qarun Lake appeared to be a good bioindicator of the recent ecological status of the lake waters affected by the artificial pollution (Ali and Fishar, 2005).

Isotope and chemical composition was also studied for ostracod Cyprideis torosa from the Qarun Lake (Keatings et al., 2007). It is worth noting that being resistant to saline and chemical conditions unfavourable for other species, it was often the only ostracod that ocurred in the modern lake 
sediments (Abdel Malek and Ishak, 1980 - here described as Cyprideis littoralis (Brady, 1938); Perthuisot et al., 1990; Keatings et al., 2007). Both the characteristics of its population and geochemistry of its valves were used to determine the lake level variation, wave energy, degree of evaporation and water salinity affected by both the groundwater input as well as precipitation and dissolution of authigenic minerals (Keatings et al., 2007). Further ostracod studies in the Qarun Lake focused on the last 2000 years recorded in over $8-\mathrm{m}$ long core collected in the deepest part of the lake (Keatings et al., 2010). At that time, nine taxa were recognised and described in detail, and then used for reconstruction of fluctuations in water depth, water salinity and its chemical composition. Changes in ion concentrations were based on variable relations of C. torosa and Limnocythere inopinata (Baird, 1843), as the former species preferred $\mathrm{Na}^{+}$and $\mathrm{Cl}^{-}$ rich waters and expansion of the latter was correlated with increased contents of $\mathrm{Na}^{+}, \mathrm{HCO}_{3}{ }^{-}$and $\mathrm{CO}_{3}{ }^{2-}$ and decreased of $\mathrm{Ca}^{2+}$. These changes were caused by intensive human activity in the Faiyum Oasis connected with farming and irrigation and its influence on local hydrology and the Nile flood intensity (Keatings et al., 2010). It must be highlighted that ostracod assemblage described by Keatings et al. (2010) differed significantly from that reported earlier by Bassiouni et al. (1985, 1986). Among nine species Cyprideis sohni Bassiouni, 1979, Cypridopsis vidua (O. F. Müller, 1776) and several species of the genus Leptocythere should be mentioned (Bassiouni et al., 1985, 1986). According to Keatings et al. (2010) a diversity of fauna could be connected with its natural changes in the lake, species rarity and partly in some differences in taxonomy and nomenclature as $C$. sohni and C. torosa could be the synonyms.

Data on somewhat older ostracod assemblages in the Faiyum Oasis are scarce. Only Boukhari and Guernet (1985) described the early Holocene ostracods represented by up to ten species with C. torosa, Darwinula cf. stevensoni (Brady et Robertson, 1870), Ilyocypris bradyi Sars, 1890, L. inopinata, Gomphocythere cf. obtusa (Sars, 1910) and the others (Boukhari and Guernet, 1985; Keatings et al., 2010).

\section{MATERIALS AND METHODS}

According to the abundance of fossils in the sediments, 6 and 29 samples were analysed for molluscs and ostracods in the FA-1 core, respectively. Malacological samples, $50 \mathrm{~cm}^{3}$ each, were collected at $5 \mathrm{~cm}$ intervals at depth 18.9-18.7 m, whereas a single bulk sample (volume of $370 \mathrm{~cm}^{3}$ ) was examined from the depth 4.0-3.5 m. Samples were macerated and washed through a $0.5 \mathrm{~mm}$ mesh, according to procedures described by Ložek $(1964,1986,2000)$ and Alexandrowicz and Alexandrowicz (2011). All shells, their identifiable apical fragments and fragments with characteristic sculpture were picked from the dried residue. Then, they were taxonomically determined under a stereoscopic microscope at magnifications up to $64 \mathrm{x}$ with reference to taxonomical keys (Brown, 1994; Götting, 2008; Welter-Schultes, 2012) and counted following Ložek's (1964) method for broken

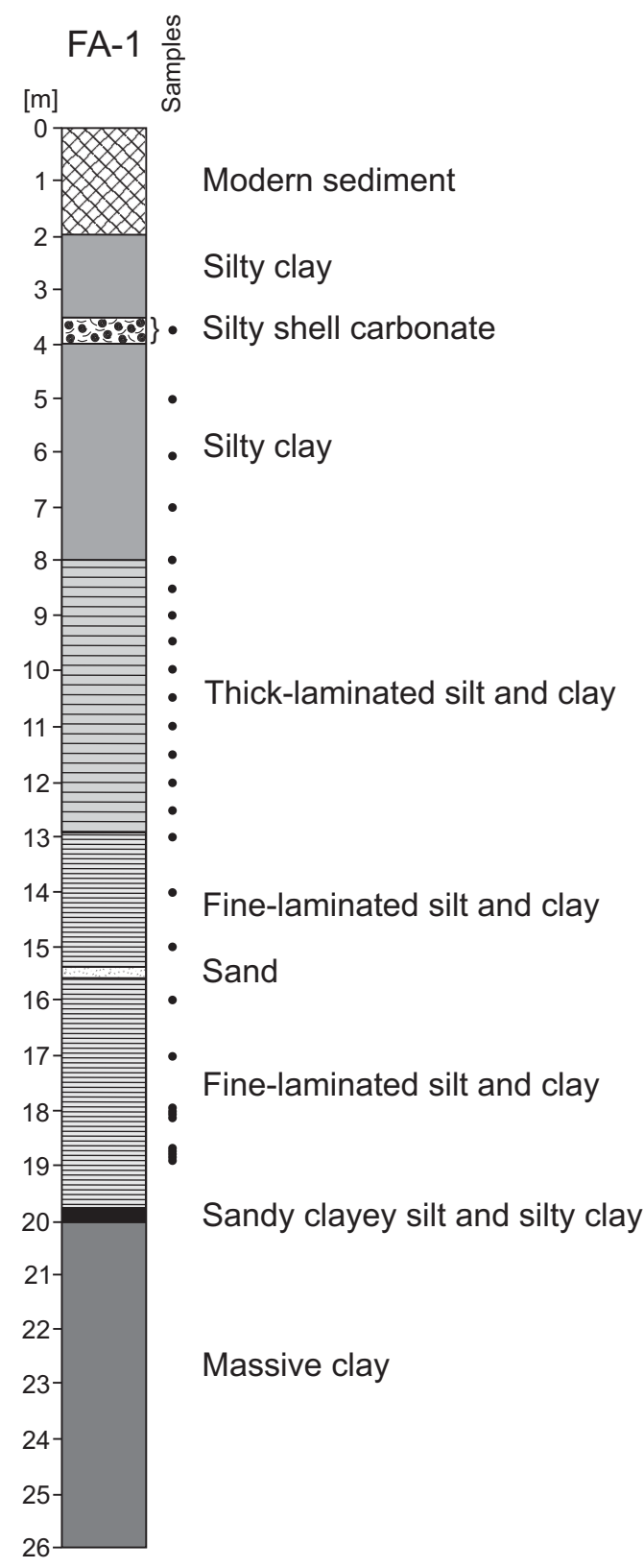

Fig. 2. Simplified lithological profile of FA-1 core (after Marks et al., 2016, modified).

individuals, which takes five shell fragments as a single complete individual (with proper corrections above 25 fragments). For bivalves the number of valves was given and some damaged specimens were determined only to the genus level (Fig. 3). Ecological preferences of mollusc species were based on Taraschewski and Paperna (1981), Brown (1994), Götting (2008), Welter-Schultes (2012) and Ghamizi et al. $(2010,2012)$.

Ostracods were collected at every $5 \mathrm{~cm}$ at depth intervals of $18.9-18.7 \mathrm{~m}$ and $18.1-17.9 \mathrm{~m}$, at every $1 \mathrm{~m}$ at the depths $17-13 \mathrm{~m}$ and $8-5 \mathrm{~m}$, and at every $0.5 \mathrm{~m}$ between 13 and $8 \mathrm{~m}$ (Fig. 3). A volume of $10 \mathrm{~cm}^{3}$ of the sediment per sample was wet-sieved with $0.1 \mathrm{~mm}$ mesh (Löffler, 1986). Ostracods were recognised under a stereoscopic microscope (magnification up to $64 \mathrm{x}$ ) according to Sywula (1974) and Keatings et al. (2010); however, some juvenile 


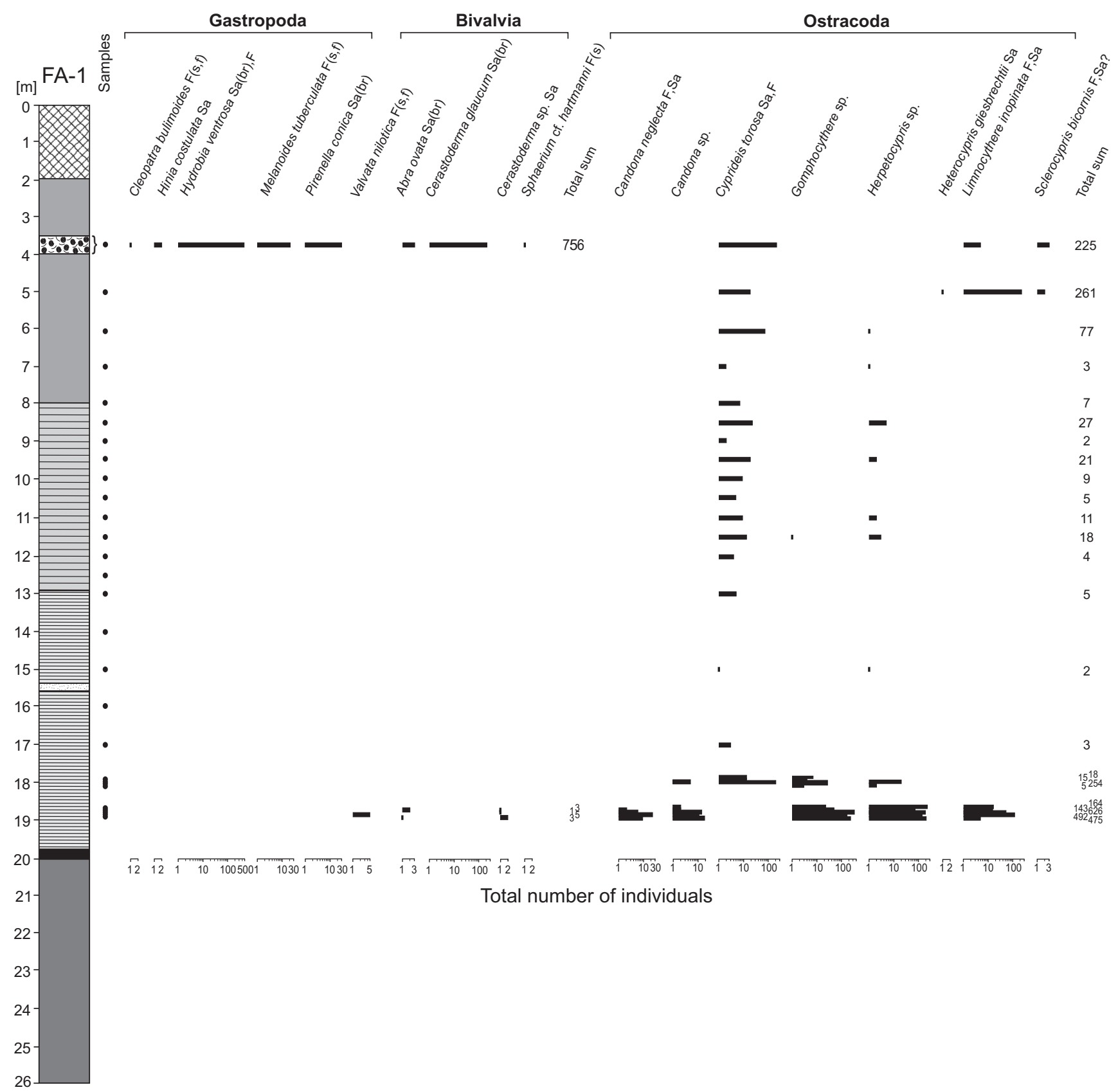

Fig. 3. Logarithmic diagram of faunal abundance in FA-1 core. Ecological preferences are given after the species name: $\mathrm{F}-$ freshwater: $\mathrm{s}-\mathrm{stagnant}$ water, $\mathrm{f}$ - flowing water; $\mathrm{Sa}$ - saltwater: br - brackish. For bivalves and ostracods a number of valves is given.

and incomplete individuals were classified only to the genus level. A number of valves was counted in each sample (Fig. 3), whereas in samples with the most abundant fossils a proportion of both the complete carapaces and the valves was used to indicate the energy regime of the lake (cf. Keatings et al., 2007, 2010).

\section{CHARACTERISTCS OF MOLLUSCS AND OSTRACODS IN FA-1 CORE}

In total, the analysed material comprises 10 taxa of molluscs (6 snails and 4 bivalves) and 8 taxa of ostracods repre- sented by 768 and 2872 individuals, respectively (Fig. 3). The lowermost samples contained very scarce mollusc remains. No shells have been found at a depth of $18.7 \mathrm{~m}$, whereas below (at a depth of 18.9-18.75 m) only 1-2 species and 1-5 individuals were noted in a single sample, with the freshwater snail Valvata nilotica endemic to the Ethiopian Highlands and the Lower Nile and some single fragments of saline bivalves Abra ovata (Philippi, 1836) and Cerastoderma sp. (Fig. 3). Abundant shells belonging to 756 individuals of 8 taxa occured in the upper part of the sequence, at a depth of 4.0-3.5 m. The mollusc assemblage was dominated by brackish species, namely Hydrobia ventrosa and Cerastoderma glaucum, accompanied by euryhaline snails Pirenella con- 

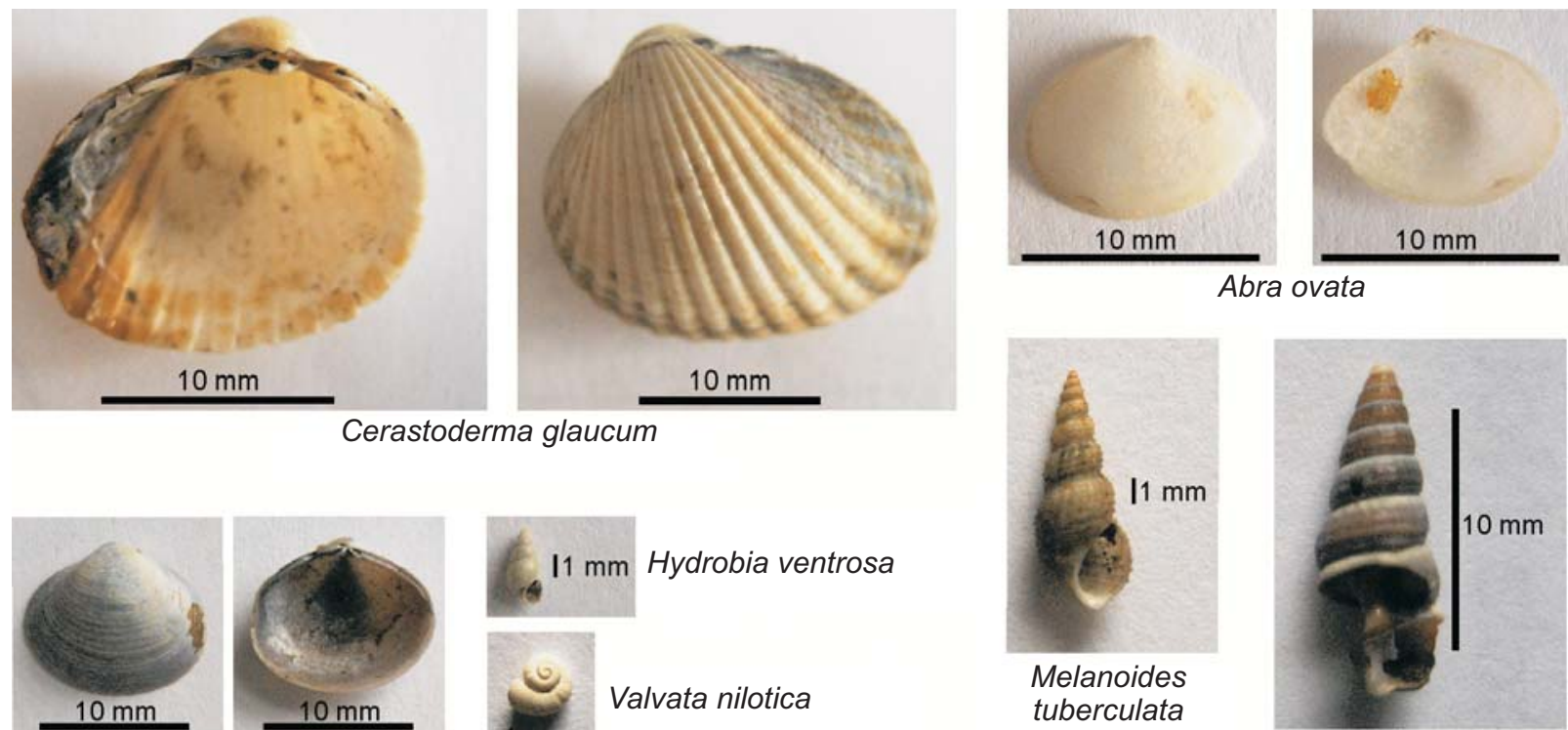

Pirenella conica

Fig. 4. Selected mollusc species in the Lake Qarun from the FA-1 core.

ica, Hinia costulata and three freshwater species: Cleopatra bulimoides, Sphaerium cf. hartmanni Jickeli, 1874 and the most abundant Melanoides tuberculata (Figs 3, 4).

The ostracod fauna of the FA-1 core outnumbered the molluscs with 8 taxa represented by 2872 individuals. A number of taxa and individuals varied from 1 to 6 and from 2 to 626 per sample, respectively. The poorest assemblages were noted at $18.05 \mathrm{~m}, 17.95-17.9 \mathrm{~m}$ and at the depth interval of 17-6 m (Fig. 3). Samples from the depth of 18.9-18.7 m were dominated by freshwater Gomphocythere sp. and juvenile and/or damage valves of Herpetocypris sp. accompanied by Limnocythere inopinata and Candona neglecta Sars, 1887, occurring both in fresh and saltwaters and in various depth conditions (common from littoral to deep profundal; Sywula, 1974). Worth noting is a lack of Cyprideis torosa, characteristic of calm, near-shore zones of brackish water bodies (Sywula, 1974; Neale, 1988; Keatings et al., 2010), which in the FA-1 core predominated at the depths of 18 and 4-3.5 m (Fig. 3), with valves all without nodes. In the highest part of the core, this species was accompanied by only single valves of $L$. inopinata and Sclerocypris bicornis (G.W. Müller, 1900) (Fig. 3).

In the FA-1 core distinct changes in the valve/carapace ratio were observed. Altogether carapaces constituted about $21 \%$ of the assemblage, changing from $22-28 \%$ in the lowermost samples, through $2.4 \%$ at a depth of $18.7 \mathrm{~m}$ to $45 \%$ in the depth interval of $4-3.5 \mathrm{~m}$.

\section{INTERPRETATION OF THE FAUNAL RECORD OF FA-1 CORE}

Relatively low volume of the examined material accompanied by a low frequency of molluscs shells in the lowermost part of the sequence made a detailed quantitative analysis impossible; however, the fauna of the FA-1 core provided some significant palaeoenvironmental data for the Qarun Lake. In general, the recognised molluscs and ostracods exhibited wide ecological tolerance occurring in both salt and freshwater bodies (Sywula, 1974; Brown, 1994; Park and Martens, 2001; Keatings et al., 2010), but various relations between characteristic species noted in several samples pointed to changes of palaeohydrological and depth conditions during deposition of lake deposits.

The fauna of the depth interval of 18.9-18.7 $\mathrm{m}$ appears to indicate freshwater environment evidenced by occurrence of Valvata nilotica and Gomphocythere sp. Single shell fragments of saltwater bivalves Abra ovata and Cerastoderma sp. might have been redeposited during drilling from the uppermost part of the core. The identification of Gomphocythere ostracods only in the rank of genus hinder further interpretations at this level, but it must be highlighted, that the Gomphocythere species were mostly reported from a soft sublittoral substrate of freshwater bodies (Park and Martens, 2001; Boomer and Gearey, 2010; Cohen et al., 2013). In Lake Qarun Gomphocythere cf. obtusa (Sars, 1910) was described by Boukhari and Guernet (1985), but due to lack of comparative material the verification of valves from FA-1 core appears impossible. In contrast, they contain distinct ventral ridge and lateral crests, which may refer to individuals from the Tanganyika Lake described as Gomphocythere n. spec. and sharing the morphological traits with Gomphocythere downingi Park and Martens, 2001 (Cohen et al., 2013). Thus, a taxonomy of the Gomphocythere sp. in the Lake Qarun requires further studies and comparisons with other African lakes and should stay open at this moment.

The faunal assemblage of the lowermost samples with scarce molluscs and abundant ostracods with Gomphocythere sp., Candona neglecta and Limnocythere inopinata could record somewhat a deeper part of the lake compared to the uppermost part of the sequence, and presumably with higher-energy conditions, suggested by a low frequency of 
carapaces (2.4-28\%) and considerable amounts of broken valves (cf. Keatings et al., 2010), especially at the depths of 18.75 and $18.7 \mathrm{~m}$. Increased content of Cyprideis torosa at the depths of $18 \mathrm{~m}$ and 4-3.5 m, and expansion of molluscs typical of saline waters in the latter (namely Hydrobia ventrosa, Cerastoderma glaucum, Cyprideis torosa), may record episodes of increased salinity in the lake. The isolated peak of C. torosa at the depth of $18 \mathrm{~m}$ (Fig. 3) is especially worth noting, as it suggests presence of a very short episode with higher salinity. It appears that after this episode some unfavourable conditions for ostracods and/or valve preservation could occur, as indicated by very scarce fauna noted between 17 and $5 \mathrm{~m}$ (Fig. 3).

Changes in the uppermost part of the core are connected with both the higher salinity and the lake shallowing, evidenced by high contents of $H$. ventrosa and C. torosa typical of shallow and calm habitats (Sywula, 1974; Götting, 2008; Welter-Schultes, 2012). The steady sedimentation in a shallow lake was also supported by considerable content of complete ostracod carapaces (45\%) and the occurrence of Pirenella conica, which avoids a wave action (Taraschewski and Paperna, 1981; Whatley, 1988; Boomer et al., 2003; Keatings et al., 2010). An admixture of freshwater species in this relatively thick sample (4-3.5 m) could suggest some shell mixing, but most of them co-occur with brackish taxa in other Egyptian lakes, whereas Melanoides tuberculata and Cleopatra bulimoides were even listed amongst the brackish snails (e.g. Sattmann and Kinzelbach, 1988).

Taking into consideration an increased salinity of the Qarun Lake, there rises a question of its salinity range. $P$. conica has the highest salinity tolerance reaching up to 90\%o (Taraschewski and Paperna, 1981). C. glaucum and A. ovata occur at 3-61\%o and 3-41\%o (Gontikaki et al., 2003), respectively, whereas $H$. ventrosa reveals the most narrow tolerance between 6 and 25\% (Götting, 2008; WelterSchultes, 2012). Based on the latter and the smooth valves of C. torosa, which occur in the salt concentrations usually higher than 14\%o (Vesper, 1975; Neale, 1988; Keyser and Aladin, 2004; Keyser, 2005), the salinity range recorded in the uppermost part of FA-1 core (4-3.5 m) can be estimated at $14-25 \%$. Moreover, at that time the lake waters appeared to be rich in $\mathrm{Na}^{+}$and $\mathrm{Cl}^{-}$, preferred by $C$. torosa, in contrast to former phase of $\mathrm{Na}^{+}, \mathrm{HCO}_{3}{ }^{-}$and $\mathrm{CO}_{3}{ }^{2-}$ predominance and low contents of $\mathrm{Ca}^{2+}$ recorded by expansion of Limnocythere inopinata at the depth of $5 \mathrm{~m}$ (cf. Keatings et al., 2010; Marks et al., 2017). Variable relations of C. torosa and $L$. inopinata were also noted in other sections of the Qarun Lake being connected with farming in the region and/or changes in the Nile supply (Keatings et al., 2010), but in the light of the faunal data presented in this paper this problem should remain open.

\section{CONCLUSIONS}

Both the composition and the structure of faunal assemblage in FA-1 core allowed for a palaeoenvironmental reconstruction of the Qarun Lake. Three phases of fauna de- velopment were distinguished. The oldest was represented by a lower part of the sequence (18.9-18.7 m depth) with scarce molluscs and numerous ostracods, when the freshwater lake was relatively deep and affected by higher wave/ currents energy. Then, at the depth of $18 \mathrm{~m}$ the first, short saline event was recorded by rapid expansion of Cyprideis torosa, followed by the phase with poor faunal assemblage. Another expansion of $C$. torosa correlated with the increase in the water salinity and the lake shallowing was documented in the upper part of FA-1 core (4-3.5 m depth). The fauna was dominated by brackish species (Hydrobia ventrosa, Cerastoderma glaucum, Pirenella conica) typical of calm, near shore zone. Smooth valves of C. torosa and abundance of $H$. ventrosa pointed at that time to the salinity range between 14 and $25 \%$.

\section{Acknowledgements}

This research has been funded by the National Science Centre in Poland, decision no. DEC-2012/05/B/ST10/00558.

\section{REFERENCES}

Abdel-Malek, S.A., Ishak, M.M., 1980. Some ecological aspects of Qarun Lake, Fayoum, Egypt. Part II. Production of plankton and benthic organisms. Hydrobiologia 75, 201-208.

Alexandrowicz, S.W., 1986. Holozäne Molluskenegemeinschaften von Oasr el-Sagha. Mitteilungen des Deutschen Archäologischen Instituts Abteilung Kairo 42, 25-34.

Alexandrowicz, S.W., 2001. A mollusc thanatocenosis in the Nile River Valley near Wadi Halfa (N Sudan). Folia Malacologica 9, 39-43.

Alexandrowicz, S.W., Alexandrowicz, W.P., 2011. Analiza malakologiczna. Metody badań i interpretacji. Rozprawy Wydziału Przyrodniczego PAU, tom 3. Wydawnictwa PAU, Kraków, 302 pp. (in Polish).

Ali, M.H.H, Fishar M.R.A., 2005. Accumulation of trace metals in some benthic invertebrate and fish species relevant to their concentration in water and sediment of Qarun Lake, Egypt. Egyptian Journal of Aquatic Research 31, 289-301.

Bassiouni, M.A., Boukhary, M., Anan, H., Bahr, S., 1985. Distribution of Cyprideis (Cyprideis) sohni in Qarun Lake, Fayum, Egypt. Revue de Paléobiologie 4, 15-34.

Bassiouni, M.A., Anan, H., Boukhary, M., Bahr, S., 1986. Ostracods from modern Qarun Lake (Fayum, Egypt). Neues Jahrbuch für Geologie und Paläontologie 172, 107-120.

Boomer, I., Gearey, B., 2010. The occurrence of a new species of Gomphocythere (Ostracoda, Limnocytheridae) in the Holocene of SE Turkey: the northernmost record for the genus. Journal of Micropalaeontology 29, 115-118.

Boomer, I., Horne, D.J., Slipper, I.J., 2003. The use of ostracods in palaeoenvironmental studies, or what can you do with an ostracod shell? In: Park, L.E., Smith, A.J. (Eds), Bridging the Gap: Trends in the ostracod biological and geological sciences. The Paleontological Society Papers 9, 153-179.

Boukhari, M., Guernet, C., 1985. Ostracodes du Pléistocène de Fayoum (Égypte): Aperçu Systématique et observations nouvelles sur les caractéristiques d'un ancient lac. Revue de Micropaléontologie 28, 32-40.

Brown, D.S., 1994. Freshwater snails of Africa and their medical importance. Taylor and Francis, London, 608 pp. 
Caton-Thompson, G., Gardner, E.W., 1934. The Desert Faiyum. Royal Anthropological Institute. London, $167 \mathrm{pp}$.

Cohen, A.S., van Bocxlaer, B., Todd, J.A., McGlue, M., Michel, E., Nkotagu, H.H., Grove, A.T., Delvaux, D., 2013. Quaternary ostracodes and molluscs from the Rukwa Basin (Tanzania) and their evolutionary and paleobiogeographic implications. Palaeogeography, Palaeoclimatology, Palaeoecology 392, 79-97.

El-Sayed, E., Guindy, K.A., 1999. Hydrochemical investigations of El Faiyum locality with special reference to the sulphate enrichment phenomenon in Qarun Lake. Bulletin of the Faculty of Science, Mansoura University 26, 1-21.

El-Shabrawy, G.I., Dumont, H.J., 2009. The Faiyum depression and its lakes. Biomed. Life Sciences 89, 95-124.

Flower, R.J., Keatings, K., Hamdan, M., Hassan, F.A., Boyle, J.F., Yamada, K., Yasuda, Y. 2012. The structure and significance of early Holocene laminated lake sediments in the Faiyum Depression (Egypt) with special reference to diatoms. Diatom Research 27, 127-140.

Gardner, E.M., 1932. Some lacustrine Mollusca from the Faiyum Depression: a study in variation. Memoires a l'Institut D'Egypte 18, $1-123$.

Ghamizi, M., Jørgensen, A., Kristensen, T.K., Lange, C., Stensgaard, A.S., Van Damme, D., 2012. Cleopatra bulimoides. The IUCN Red List of Threatened Species. Version 2014.2. <www.iucnredlist.org>. Downloaded on 15 October 2014.

Ghamizi, M., Kristensen, T.K., Stensgaard, A.-S., Van Damme, D., 2010. Musculium hartmanni. The IUCN Red List of Threatened Species. Version 2014.3. <www.iucnredlist.org > . Downloaded on 17 November 2014.

Gontikaki, E., Antoniadou, C., Chintiroglou, C.C., 2003. Population structure of Cerastoderma glaucum and Abra ovata in Vouliagmeni Lagoon (Attiki). Journal of the Marine Biological Association of the United Kingdom 83, 1095-1097.

Götting, K.-J., 2008. Meeres-Gehäseschnecken Deutschlands. Bestimmungsschlüssel, Lebensweise, Verbreitung. Die Tierwelt Deutschlands, 80. ConchBooks, Hackenheim.

Hassan, F.A., Hamdan, M.A., Flower, R.J., Keatings, K., 2012. The oxygen and carbon isotopic records in Holocene freshwater mollusc shells from the Faiyum palaeolakes, Egypt: Their palaeoenvironmental and palaeoclimatic implications. Quaternary International 266, 175-187.

Hughes, R.H., Hughes, J.S., 1992. A Directory of African Wetlands. IUCN, Gland, Switzerland and Cambridge, UK - UNEP, Nairobi, Kenya - WCMC, Cambridge, UK, 820 pp.

Keatings, K.W, Hawkes, I., Holmes, J.A., Flower, R.J., Leng, M.J., AbuZied, R.H., Lord, A.R., 2007. Evaluation of ostracod-based palaeoenvironmental reconstruction with instrumental data from the arid Faiyum Depression, Egypt. Journal of Paleolimnology 38, 261-283.

Keatings, K., Holmes, J., Flower, R., Horne, D., Whittaker, J.E., AbuZied, R.H., 2010. Ostracods and the Holocene palaeolimnology of Qarun Lake, with special reference to past human-environment interactions in the Faiyum (Egypt). Hydrobiologia 654, 155-176.

Keyser, D., 2005. Histological peculiarities of the noding process in $\mathrm{Cy}$ prideis torosa (Jones) (Crustacea, Ostracoda). Hydrobiologia 538, 95-106.

Keyser, D., Aladin, N., 2004. Noding in Cyprideis torosa and its causes. Studia Quaternaria 21, 19-24.

Ložek, V., 1964. Quartärmollusken der Tschechoslowakei. Rozpravy Ústředního ústavu geologického 31, 1-374.

Ložek, V., 1986. Mollusca Analysis. In: Berglund, B.E. (Ed.), Handbook of Holocene Palaeoecology and Palaeohydrology, 729-740, John Wiley \& Sons, Chichester - New York - Brisbane - Toronto - Singapore.
Ložek, V., 2000. Palaeoecology of Quaternary Mollusca. Antropozoikum 24, 35-59.

Löffler, H.W., 1986. Ostracod analysis. In: Berglund, B.E. (Ed.), Handbook of Holocene Palaeoecology and Palaeohydrology, 693-702, John Wiley \& Sons, Chichester - New York - Brisbane - Toronto - Singapore.

Marks, L., Salem, A., Welc, F., Nitychoruk, J., Chen, Z., Blaauw, M., Zalat, A., Majecka, A., Szymanek, M., Chodyka, M., TołoczkoPasek, A., Sun, Q., Zhao, X., Jiang, J. 2017. Holocene lake sediments from the Faiyum Oasis in Egypt: a record of environmental and climate change. Boreas, in press.

Marks, L., Salem, A., Welc, F., Nitychoruk, J., Zhongyuan, C., Zalat, A., Majecka, A., Chodyka, M., Szymanek, M., Tołoczko-Pasek, A. 2016. Preliminary report on unique laminated Holocene sediments from the Qarun Lake in Egypt. Studia Quaternaria 33, 35-46.

Martens, E., 1879. Subfossile Suesswasser Conchylien aus dem Fajum. Sitzungsberichte der Gesellschaft Naturforschender Freunde zu Berlin, 100-102.

Naguib, M., 1961. Studies on the ecology of Qarun Lake (Fayum, Egypt). Part II. Kieler Meeresforschungen 17, 94-131.

Neale, J.V., 1988. Ostracods and paleosalinity reconstruction. In: De Deckker, P., Colin, J.P., Peypouquet, J.P. (Eds), Ostracoda in the Earth Sciences, 125-155, Elsevier, Amsterdam.

Park, L.E., Martens, K., 2001. Four new species of Gomphocythere (Crustacea, Ostracoda) from Lake Tanganyika, East Africa. Hydrobiologia 450, 129-147.

Perthuisot, J.P., Guelorget, O., Ibrahim, A.W.S., Margerel, J.P., Maurin, A., Piron-Frenet, M., 1990. Organisation hydrochimique, biologique et sédimentologique d'un lac intracontinental à peuplements lagunaires: la Birket Karoun (Fayoum, Egypte). Geodinamica Acta 4, 73-89.

Revel, M., Colin, C., Bernasconi, S., Combourieu-Nebout, N., Ducassou, E., Grousset, F.E., Rolland, Y., Migeon, S., Bosch, D., Brunet, P., Zhao, Y., Mascle, J., 2014. 21,000 Years of Ethiopian African monsoon variability recorded in sediments of the western Nile deep-sea fan. Regional Environmental Change 14, $1685-1696$.

Sattmann, H., Kinzelbach, R., 1988. Notes on inland water molluscs from Egypt (Mollusca: Gastropoda, Bivalvia). Zoology in the Middle East 2, 72-78.

Sywula, T., 1974. Ostracods (Ostracoda) (Małżoraczki (Ostracoda). Fauna słodkowodna Polski 24, 5-315. Państwowe Wydawnictwo Naukowe, Poznań.

Taraschewski, H., Paperna, I., 1981. Distribution of the snail Pirenella conica in Sinai and Israel and its infection by Heterophydae and other Trematodes. Marine Ecology - Priogress Series 5, 193-205.

Vesper, B., 1975. To the problem of noding on Cyprideis torosa (Jones, 1850). Bulletin of American Paleontology 65, 205-216.

Welc, F., 2016. Holocene climate change in the Lower Nile Basin based on geoarchaeologcal data from the Faiyum Oasis (Egypt) (Holoceńskie zmiany klimatu w dorzeczu dolnego Nilu w świetle danych geoarcheologicznych z Oazy Fajum (Egipt). Wydawnictwo Stowarzyszenia Naukowego Archeologów Polskich, Warszawa, 332 pp. (in Polish with English summary).

Welter-Schultes, F., 2012. European non-marine molluscs, a guide for species identification. Planet Poster Editions, Goettingen, $679 \mathrm{pp}$.

Wendorf, F., Schild, R., 1976. The Prehistory of the Nile Valley. Academic Press, New York.

Whatley, R.C., 1988. Population structure of ostracods: some general principles for the recognition of palaeoenvironments. In: De Deckker, P., Colin, J.P., Peypouquet, J.P. (Eds), Ostracoda in the Earth Sciences, 245-256, Elsevier, Amsterdam. 